Nobel Prize for Physiology :

\section{Dr. Georg von Békésy}

THE award to Dr. Georg von Békésy of the 1961 Nobel Prize for Physiology gives recognition to a remarkable achievement in the field of experimental biophysics. Dr. Békésy has had an unusual career. Born in 1899 in Budapest and educated at the Universities of Bonn and Budapest, he has, since 1949 , been senior research fellow in psychophysics at Harvard. He has displayed outstanding skill as an experimenter, devising at all stages of his work new technical equipment, mechanical, optical and electrical, of great ingenuity. His first remarkable contribution was a penetrating analysis of the vibrational responses to pure tones of the basilar membrane of the human cochlea. A later outstanding achievement was his use of vibrating electrodes to explore and reconstruct the patterns of amplitude and direction of vibration induced in individual cell elements within the cochlea in response to pure tones of varying frequency and intensity. His papers, written in clear, concise and graphic language, have exercised a profound effect on our concepts of the peripheral mechanism of hearing. An edited selection of his earlier German papers has recently been translated into English by Prof. E. G. Wever, one of his American colleagues, and republished together with others in book form, Experiments in Hearing. This is a substantial volume of 750 pages and incorporates a representative bibliography of the author's papers. In 1961 Dr. von Békésy was awarded the Gold Medal of the Acoustical Society of America.

\section{The Education Bill in Great Britain}

THE Education Bill, which received its second reading in the House of Commons on November 13, has two purposes. The first is to provide statutory authority for the reforms in the system of grants to students which were announced following the report of the Anderson Committee; the second is to reduce to two the number of school-leaving dates in the year, as recommended by the Central Advisory Council for England and Wales in the Crowther Report. In moving the second reading of the Bill, the Minister of Education, Sir David Eccles, said that the local authorities, with which he had fully discussed the provisions of the Bill, readily accepted that the time had come to make the awards automatic when the student had both the qualifications and a place at a university, and Clause 1 laid this duty on the authorities as from September 1962, and gave the Minister power to define the extent of the duty. Sir David said that he had accepted the Anderson Committee's recommendation that the qualifications for an award should be two A-level passes in the General Certificate of Education, but it is necessary to provide for further qualifications which students may gain as they advance in technical colleges. Clause 2 ensured that local authorities had full discretion to make awards for further education courses below the standard comparable with first-degree courses.

The second fundamental principle of the new system is uniformity of treatment. Sir David said that local education authorities now generally accept for the student's own maintenance during term the standard figures reviewed at intervals by their representatives and the Ministry. In future there would be nationally prescribed rates and conditions of grant binding on all authorities for all items of a student's grant which could be dealt with in this way. It was proposed to retain the means test in a relaxed way which would relieve about 10,000 more families from all contributions and those in the middle range of incomes would pay substantially less. Grants for students in teacher-training colleges would be calculated in the same way as for university students, and those for students in technical colleges taking full-time courses comparable with degree courses would be similarly calculated. The standard vacation grant had been revised and now applies throughout the income range of parents, while conditions for dependants' grants have been revised and broadened. Students may keep up to $£ 100$ of private income, including income from scholarships and prizes, without deduction from their grant, and the Minister said he had appointed a Standing Advisory Committee with Sir Francis Hill as chairman to advise on matters relating to the size of the grant and the definition of 'comparable courses'. The Committee had been asked to recommend revised rates of grant early in the New Year.

Sir David said that under our present policies, the cost of education in Britain is rising at about 5 per cent a year, and awards to students now cost $£ 35$ million a year. What is proposed under the Bill would add a further $£ 10$ million. To abolish the means test altogether would add another $£ 10$ million, and Sir David said that if he and the Secretary of State for Scotland were allowed to spend a second $£ 10$ million, they thought they could spend it to better advantage in other parts of the service. Under Clause 3 of the Bill, State Scholarships would disappear, but the Minister intends to retain the scheme for mature State scholars, and his powers to operate the State studentship scheme of awards for postgraduate students in arts subjects are also continued. As regards school leaving, under the Bill a child who reaches fifteen in the months September-January must stay at school until the end of the Easter term; if he reaches fifteen after the end of January, he must stay to the end of the summer term. The Bill also applies to Scotland the automatic awards, uniformity of treatment, revised income scale and other improvements, but the Scottish Education Department will itself make the awards to students in universities and similar institutions of higher education.

\section{Scientists and Engineers in the U.S. Federal \\ Government}

A REPORT, Scientists and Engineers in the Federal Government, October 1958 (NSF 61-43. Pp. vi +44. (Washington, D.C.: Government Printing Office, 1961.) 35 cents), issued by the National Science Foundation, also includes some data on trends in Federal employment of scientists and engineers since the previous report (covering the year 1954). In 1958 the Federal Government employed about 8 per cent of all full-time 'white-collar' workers, an increase of 20 per cent on 1954. Of these 121,000, 55,000 were engineers, 21,000 were biological scientists and 18,000 physical scientists. The Department of Defense was the largest employer, and some 75 per cent of the total were employed outside the District of Columbie. About 42,000 were engaged in research and development, more than half being in the Department of Defense and 20 per cent in the physical sciences. About 100,000 technicians were employed by the Federal Government, 35,000, including 21,000 engaged in nursing, being employed in the health fields; 